\title{
PROPER PREEMPTION OR CONTRIVED CONSTRUCTION?: WHY SECTION 360K(A) OF THE FDCA SHOULD NOT BE INTERPRETED TO PREEMPT STATE COMMON LAW TORT ClAIMS
}

\author{
Travis P. Meek*

\section{INTRODUCTION}

Pursuant to Section 360k(a) of the Federal Food, Drug, and Cosmetic Act, a state may not impose requirements on a medical device that are different from, or in addition to, the requirements already imposed upon the device by the Federal Food and Drug Administration ("FDA"). ${ }^{1}$ While this express preemption provision may appear straightforward on its face, a question remains regarding its effect on state common law tort claims, such as negligence and strict liability, when the device in question has been approved through the FDA's rigorous pre-market approval process. Several courts, such as the Third, Seventh, and Ninth Circuit Courts of Appeals, have concluded that state common law tort claims involving federally approved medical devices are expressly preempted by Section $360 \mathrm{k}(\mathrm{a})$ because they represent an attempt to impose state requirements upon medical devices that are different from, or in addition to, federal requirements. ${ }^{2}$ On the other hand, the Tenth and Eleventh Circuit Courts of Appeals have reached the opposite conclusion, declaring that state common law tort claims are not preempted by Section $360 \mathrm{k}(\mathrm{a})$, either because the state claims are too general to be regarded as imposing specific, conflicting requirements, ${ }^{3}$ or because the federal medical device approval process does not impose substantive requirements on devices with which a state requirement could possibly conflict. ${ }^{4}$ The Supreme Court

* J.D., 2005, Indiana University School of Law - Indianapolis; B.A., 2001, Dartmouth College, Hanover, New Hampshire. I would especially like to express my gratitude to my mother, father, and siblings, Frank, Caroline, and Sarah, for their lifelong encouragement and support. In addition, I would like to thank Dr. Brad Kallmyer and Daniel Byron for the helpful suggestions and invaluable insight they provided me while I wrote this note.

1. 21 U.S.C. $\S 360 \mathrm{k}(\mathrm{a})(2005)$. The statute provides:

(a) General rule[.] Except as provided in subsection (b) of this section, no State or political subdivision of a State may establish or continue in effect with respect to a device intended for human use any requirement- - (1) which is different from, or in addition to, any requirement applicable under this chapter to the device, and (2) which relates to the safety or effectiveness of the device or to any other matter included in a requirement applicable to the device under this chapter.

2. Horn v. Thoratec Corp., 376 F.3d 163 (3d Cir. 2004); Mitchell v. Collagen Corp., 126 F.3d 902 (7th Cir. 1997); Papike v. Tambrands, Inc., 107 F.3d 737 (9th Cir. 1997).

3. Oja v. Howmedica, Inc., 111 F.3d 782 (10th Cir. 1997).

4. Goodlin v. Medtronic, Inc., 167 F.3d 1367 (11th Cir. 1999). 
of the United States has yet to resolve the circuit split. ${ }^{5}$ Nonetheless, through its fractured 1996 plurality opinion in Medtronic, Inc. v. Lohr, the Court appears to suggest that Section $360 \mathrm{k}$ (a) should not be interpreted as preempting most state common law tort claims involving medical devices. ${ }^{6}$

The ensuing discussion will advocate the uniform adoption of the Tenth Circuit's approach to this conflict by all courts. State common law tort claims merely involve the imposition of general requirements, such as the duty to use good care in manufacturing, therefore, they cannot possibly conflict with federally imposed requirements and are not preempted by Section $360 \mathrm{k}(\mathrm{a})$. This approach is favorable because it most accurately reflects Congressional intent to adhere to the presumption against federal preemption of state public health and safety regulations suggested by the Supreme Court, ${ }^{7}$ and it serves important public policy considerations.

The most effective method of accomplishing the uniform interpretation of Section $360 \mathrm{k}(\mathrm{a})$ would be through a Congressional amendment to the statute. In the absence of Congressional action, however, the FDA could issue a clarification regulation directly addressing Section $360 \mathrm{k}(\mathrm{a})$ 's preemptive reach, or the Supreme Court could settle the debate by granting certiorari to hear a case involving this issue. Regardless of the method by which it occurs, it is imperative for the legal community to arrive at a consistent understanding of the preemptive scope of Section $360 \mathrm{k}(\mathrm{a})$, preferably one that adopts a narrow interpretation.

Part I of this Note describes the facts and outcome of the recently decided Third Circuit Court of Appeals case, Horn v. Thoratec, Corp., in order to illustrate the real-world context within which the present issue arises. Part II of this Note addresses the 1976 Amendments to the Food, Drug, and Cosmetic Act ("FDCA"), with particular emphasis placed on the Pre-Market Approval process for medical devices. Part III then discusses the different interpretations of Section $360 \mathrm{k}(\mathrm{a})$ 's preemptive effect held by the Supreme Court and the Circuit Courts of Appeals. Part IV proposes that the Eleventh Circuit was correct in concluding that Section $360 \mathrm{k}$ (a) does not preempt state tort claims, but suggests that the court's reasoning was flawed. Part V explains that the Tenth Circuit was correct, not only in its conclusion that Section 360k(a) does not preempt state tort claims, but also in its reasoning. Part VI discusses the appropriate amount of weight that courts should afford to amicus curiae briefs submitted by government agencies, and suggests that

5. See, e.g., Medtronic, Inc. v. Lohr, 518 U.S. 470, 495 (1996) (where the Supreme Court declared, "[t] $]$ he different views expressed by the Courts of Appeals regarding the appropriate scope of federal pre-emption under [Section] 360k demonstrate that the language of that section is not entirely clear."). See also, Wilson v. Bradlees of New Eng., Inc., et al., 96 F.3d 552, 556 (1st Cir. 1996) (explaining that, "[f]or the moment, the Supreme Court's inclination is balanced almost on a knife edge, as the divisions in Lohr amply confirm.").

6. Lohr, 518 U.S. at $470-71$.

7. Id. at 484-85. 
the Third Circuit gave undue deference to the FDA's amicus brief in Horn $v$. Thoratec, Corp. Part VII concludes this Note by reiterating the superiority of the Tenth Circuit's interpretation of Section $360 \mathrm{k}$ (a) and offers suggestions for the means by which such an approach could be uniformly adopted by the entire legal community.

\section{RECENT TREATMENT OF THE ISSUE: HORN V. THORATEC, CORP.}

\section{A. Facts}

On January 17, 1998, Daniel Ray Horn was admitted to Williamsport Hospital in Williamsport, Pennsylvania after suffering an acute myocardial infarction. ${ }^{8}$ Soon after his arrival, Horn was transferred to Hershey Medical Center, where the attending physicians concluded that he desperately needed a heart transplant in order to stay alive. Five days later, while waiting for a suitable transplant donor, Horn's condition worsened. As a result, Horn and the doctors at Hershey agreed on the insertion of a heart pump to assist his heart in circulating blood throughout his body while he waited for a donor. The heart pump the Hershey doctors chose for the procedure was one manufactured by Thoratec Corporation," called the "HeartMate LVAD."10 This device contains a central pump "body," with two major tubes extending from each side. One of the tubes connects directly to the heart and is designed to pump blood from the heart's ventricle into the pump body. This side of the pump is called the "inlet side." Once blood has entered the pump body through the inlet side, it then exits the pump body through the other tube located on the "outlet side" which is connected directly to the aorta. Once blood flows through the outlet side into the aorta, it is dispersed throughout the body. In addition to the pump body, both of the major tubes are connected to a circle-shaped pump housing, to which a third tube is also connected. This third tube is designed to exit the body and connect to an air compressor, which forces air through the tube and into a pump, thereby assisting the heart's

8. "Myocardial Infarction" is the medical term for heart attack. Taber's Cyclopedic Medical Dictionary defines it as "[d] ]evelopment of an infarct in the myocardium, usually the result of myocardial ischemia following occlusion of a coronary artery." Its symptoms include "[p]ain similar to that of angina pectoris, shock, cardiac failure with arrhythmia, and frequently sudden death." TABER's CYCLOPEDIC MEDICAL DICTIONARY M-80 (Clayton L. Thomas ed., 13th ed. 1973).

9. Thoratec Corporation was formerly known as Thermo Cardiosystems, Inc. When Barbara Horn brought suit against Thoratec in the Middle District Court of Pennsylvania following her husband's death, the named defendant was "Thermo Cardiosystems, Inc." Horn v. Thoratec Corp., 299 F.Supp.2d 381 (M.D. Penn. 2002).

10. "LVAD" stands for "Left Ventricular Assist Device." It is worth mentioning that the HeartMate LVAD is pre-assembled when it arrives at the surgeon; no further assembly is required before implantation. Horn, 376 F.3d at 164 n.3. 
circulation of blood from the ventricle to the aorta, via the two major tubes already described.

On May 3, 1998, Horn began experiencing problems with his HeartMate LVAD, evidenced by bleeding at the location where the air compressor tube exited his body. Consequently, he returned to Hershey Medical Center where an experienced cardiothoracic surgeon, Dr. Benjamin Sun, performed exploratory surgery to determine the source of the problem. Upon closely examining Horn's HeartMate, Dr. Sun discovered that the outlet tube had become disconnected to the pump housing at a point known as the "elbow." Designed to connect the outlet pump and the pump housing, the elbow is an integral part of a fully functioning HeartMate. In Horn's case, however, the screw ring that connected the elbow to the pump housing had become disconnected, thus disrupting the flow of blood through the HeartMate. Although Dr. Sun immediately attempted to reconnect the elbow to the pump housing using a metal wire instead of the screw ring, he was unable to save Horn's life. The disconnection had allowed an air embolus ${ }^{11}$ to travel to Horn's brain, which caused him to suffer a fatal brain hemorrhage. He was pronounced dead on May 8, 1998.

\section{B. The Trial}

Following her husband's death caused by the poorly constructed HeartMate, Barbara Horn brought suit against Thoratec Corporation in the Middle District Court of Pennsylvania, alleging claims of negligence, strict liability, and breach of warranty. ${ }^{12}$ In response, Thoratec moved for summary judgment, arguing that Mrs. Horn's claims were preempted by Section 360k(a)

11. Taber's Cyclopedic Medical Dictionary defines "embolus" as:

[a] mass of undissolved matter present in a blood or lymphatic vessel brought

there by the blood or lymph current. Emboli may be solid, liquid, or gaseous.

Other emboli may consist of bits of tissue, tumor cells, globules of fat, air bubbles, clumps of bacteria, and foreign bodies such as bullets. Emboli may arise within the body or they may gain entrance from without. Occlusion of vessels from emboli usually results in the development of infarcts.

TABER's CYCLOPEDIC MEDICAL DICTIONARY E-19 (Clayton L. Thomas ed., 13th ed. 1973).

Furthermore, an "air embolus" is "[a]n air bubble in the veins, right atrium or ventricle, or capillaries." TABER'SCYCLOPEDICMEDICALDICTIONARY E-19 (Clayton L. Thomas ed., 13th ed. 1973).

12. Specifically, Mrs. Horn's negligence claims included: “1) failure to test and study adequately the HeartMate; 2) failure to provide adequate warnings regarding the possibility that the screw ring may disconnect; 3 ) failure to provide adequate instructions to physicians; and 4) failure to use proper suture material." Additionally, Mrs. Horn's strict liability claims included: "1) failure to use 'good manufacturing practices'; and 2) failure to provide adequate warnings." Finally, Mrs. Horn specifically alleged that Thoratec "breached the implied warranties of merchantability and fitness." Horn v. Thermo Cardiosystems, Inc., 229 F. Supp. 2d 381, 385 (M.D. Pa. 2002). 
of the Federal Food, Drug, and Cosmetics Act ("FDCA"). ${ }^{13}$ According to this section of the FDCA:

[N]o State or political subdivision of a State may establish or continue in effect with respect to a device intended for human use any requirement-

(1) which is different from, or in addition to, any requirement applicable under [the FDCA] to the device, and

(2) which relates to the safety or effectiveness of the device or to any other matter included in a requirement applicable to the device under [the FDCA]. ${ }^{14}$

Thoratec argued that a state common law tort claim, such as those set forth in Mrs. Horn's complaint, would impose requirements on its HeartMate that would be different from, or in addition to, the requirements already imposed upon it by the FDA. Accordingly, Thoratec argued that the express preemption provision contained in Section $360 \mathrm{k}(\mathrm{a})$ entitled it to summary judgment.

In response to Thoratec's motion for summary judgment, the Middle District Court of Pennsylvania agreed with Thoratec's reasoning and granted the motion. Basing this decision on a close reading of Section $360 \mathrm{k}(\mathrm{a})$, the court declared that "[t]he key .... is to focus first on the specificity and applicability of the federal requirement and second, if necessary, on whether the state claim is different from or in addition to the federal requirement."15 As the HeartMate's safety and effectiveness was verified through the FDA's rigorous pre-market approval ("PMA") process, the court decided that specific federal requirements had been imposed upon the HeartMate, to which no state requirement could add or differ. ${ }^{16}$ The court's next task was to determine whether Mrs. Horn's state common law tort claims represented an attempt to impose additional or different requirements upon the HeartMate. Reasoning that because most of Mrs. Horn's claims related to the design and effectiveness of HeartMate, which the FDA had already addressed and approved through its PMA process, the court concluded that the state common law tort claims at issue were preempted by Section $360 \mathrm{k}(\mathrm{a})$, declaring that "[a]ny judgment that the HeartMate was unsafe or otherwise substandard would be in direct conflict-i.e., different from-the FDA's determination that the product was suitable for use."17 Accordingly, the court granted Thoratec's motion for summary judgment.

13. 21 U.S.C. $\S 301$ et seq. (2005).

14. 21 U.S.C. $\$ 360 \mathrm{k}(\mathrm{a})(1)(2005)$.

15. Horn, 229 F. Supp. 2d at 390.

16. Id. at 389 .

17. Id. at 390 . 


\section{The Appeal}

Understandably discontented with the district court's decision, Mrs. Horn appealed the judgment to the United States Court of Appeals for the Third Circuit. ${ }^{18}$ The central argument on appeal was that the state common law claims merely imposed the "generally applicable duties to use good care in manufacturing" and to issue adequate warnings of the device's risks. ${ }^{19}$ Thus, Mrs. Horn contended that the state claims should not be preempted by Section 360k(a) because they do not impose specific requirements that are different from, or in addition to, the federal, PMA-imposed requirements. ${ }^{20}$

However, as the Third Circuit, in an opinion written by Judge Garth, agreed with the district court on all grounds and upheld the grant of summary judgment to Thoratec. ${ }^{21}$ The court stated that "[b]ecause these state common law claims and duties are in severe tension with [Section] 360k(a) in that they are either in addition to, or different from, the federal requirements established by the FDA in approving the HeartMate, they are necessarily preempted by federally imposed PMA requirements under [Section] 360k(a)."22 More specifically, the court noted the following:

Because the design of the HeartMate, the labeling and the instructions for its use, and the specification of the suture and its location when the HeartMate is implanted, as well as the other requirements imposed by the PMA, were the subject of extensive consideration by the FDA leading up to its PMA approval, any finding in Horn's favor based on her general claims of negligence or defective design and manufacture--be it by a jury or a court--would necessarily amount to a state substantive requirement "different from, or in addition to, the federal requirements imposed by the FDA." ${ }^{.23}$ Any such finding would "stand as an obstacle to the accomplishment and execution of" the objective of the safety and effectiveness of the HeartMate specifically and would conflict with the federal requirements imposed by the PMA. ${ }^{24}$

18. Horn, 376 F.3d at 163.

19. Id. at 166.

20. Id.

21. Id. at 164 (Mrs. Horn's appeal was brought before a three-judge panel, consisting of Judges Ambro, Fuentes, and Garth).

22. Id. at 177. (2000))

23. Horn, 376 F.3d at 163 (quoting Geier v. Am. Honda Motor Co., 529 U.S. 861, 873

24. Id. 
In reaching its decision, the court admitted that it was heavily influenced by the sentiments expressed by the FDA in its amicus curiae brief. ${ }^{25}$ Most notably, the court relied on the FDA's opinion that state common law actions of this nature are inappropriate because they threaten the federal regulatory framework for medical devices by encouraging lay judges and juries to second-guess decisions made by the experts at the FDA regarding medical device safety and effectiveness. ${ }^{26}$

Interestingly, however, the court's decision to affirm the district court's grant of summary judgment was met with vigorous dissent by one of the three judges on the panel, Judge Julio Fuentes. While conceding that the PMA process "is a specific federal regulation governing the HeartMate," Judge Fuentes argued that Mrs. Horn's state common law claims did not seek to impose any specific requirement on the HeartMate, and therefore, should not be preempted by Section $360 \mathrm{k}(\mathrm{a}){ }^{27}$ Rather, Mrs. Horn's common law claims sought to impose requirements of general applicability, which 21 C.F.R. Section $808.1(d)(1)^{28}$ clearly removes from Section $360 \mathrm{k}$ (a)'s preemptive realm. ${ }^{29}$ Fuentes supported his position, not only with the federal regulation and favorable case law, but also with persuasive policy rationale, stating that, because the congressional purpose underlying the PMA process is to ensure consumer safety, state common law suits, which work to hold device manufacturers responsible for the harm caused by their products, are integral to attaining Congress' goal. ${ }^{30}$ Nevertheless, Mrs. Horn's case, having been summarily adjudged in Thoratec's favor, rendered her without remedy for her husband's death and relieved Thoratec of any responsibility for the harm caused by its faulty product. Following the Third Circuit's decision in favor of Thoratec, counsel for Mrs. Horn did not apply to the Supreme Court for a writ of certiorari. ${ }^{31}$

As Mrs. Horn's unfortunate situation demonstrates, the legal community is presently engaged in a heated debate regarding the proper interpretation of the nature and extent of Section $360 \mathrm{k}$ (a)'s preemptive effect. Do general state common law tort claims involving the safety and effectiveness of medical

25. Id. at 177 (where the court explicitly declared that its "preemption conclusion [was] reinforced by the informed analysis found in the FDA's amicus curiae brief.").

26. Id. at 178.

27. Id. at 180.

28. 21 C.F.R. $\S 808.1(d)(1)(2005)$ reads as follows:

Section [360k(a)] does not preempt State or local requirements of general applicability where the purpose of the requirement relates either to other products in addition to devices (e.g., requirements such as general electrical codes, and the [UCC] (warranty of fitness)), or to unfair trade practices in which the requirements are not limited to devices.

29. Horn, 376 F.3d at 182.

30. Id. at 185.

31. Telephone Interview with Gary A. Winters, Partner, Mayer, Brown, Rowe, \& Maw, LLP, in Washington D.C. (Feb. 24, 2005) (Mr. Winters was counsel for Thoratec Corp.). 
devices impose requirements upon medical devices that are different from, or in addition to, federally imposed PMA requirements, thus rendering them preempted by Section $360 \mathrm{k}(\mathrm{a})$; or do the state claims merely impose generalized duties of care that are fundamentally consistent with the federal requirements, thereby leaving them outside of Section $360 \mathrm{k}(\mathrm{a})$ 's preemptive scope? The following discussion will attempt to demonstrate why the latter interpretation is preferable, thereby advocating its uniform adoption by all U.S. courts. ${ }^{32}$

\section{THE 1976 MedicAl DEVICE AMENDMENTS AND THE PMA PROCESS}

Following a rash of consumer suits against the manufacturers of medical devices in the early 1970 s, especially those involving the alleged defects of the Dalkon Shield intrauterine device, ${ }^{33}$ Congress attempted to ease public concern regarding the safety and effectiveness of medical devices by passing the 1976 Medical Device Amendments to the FDCA, codified at 21 U.S.C. Section 360.34 Among other things, the Medical Device Amendments "confer[ ] broad regulatory authority over medical devices on the FDA and establish [ ] a regulatory framework that classifies devices by the degree of risk posed to the public, subjecting devices that pose the greatest risk to the most exacting level of FDA scrutiny." "35 The classification framework consists of three different categories: Class I devices are deemed to pose the least amount of risk, and are therefore subject to the lowest level of scrutiny; Class II devices are deemed to pose an intermediate amount of risk; and Class III devices are deemed to pose the greatest amount of risk, and are therefore subject to the highest degree of scrutiny. ${ }^{36}$

Class III devices are defined as those which are either to be used for supporting or sustaining human life, are of substantial importance in preventing impairment of public health, or present a potential unreasonable risk of illness or injury. This classification includes pacemakers and heart

32. An alternative approach to that of the present discussion (and one that is embraced by the Eleventh Circuit Court of Appeals) is to argue that state claims are not preempted by Section 360k(a) because the federal PMA process does not impose device-specific requirements with which a state claim could possibly conflict. While the present discussion will focus on the general, and therefore un-preemptable, nature of state common law claims, instead of the PMA process's lack of specificity, readers should see Sasha B. Reiders, Note, State Law Tort Claims and the FDA: Proposing a Consumer-Oriented Prescription in Medical Device Cases, 25 CARDOZOL. REV. 1159 (2004), as well as Part IV of this Note, for a thorough discussion of that alternative approach.

33. See, e.g., In re A.H. Robins, Co., Inc. “Dalkon Shield” IUD Products Liab. Litig., 406 F. Supp. 540 (J.P.M.L. 1975); Gregory J. Scandaglia \& Therese L. Tully, Express Preemption and Premarket Approval Under the Medical Device Amendments, 59 FOOD \& DRUG L.J. 245, 246 (2004).

34. Goodlin v. Medtronic, Inc., 167 F.3d 1367, 1369 (11th Cir. 1999).

35. Webster v. Pacesetter, Inc., 171 F. Supp. 2d 1, 4 (D.C. Dist. 2001).

36. 21 U.S.C. \& 360c(a)(1) (2005); Horn, 229 F. Supp. $2 d$ at 385. 
pumps, such as the HeartMate LVAD. ${ }^{37}$ In order to market a Class III device within the United States, a manufacturer must submit its product to the FDA in order for it to undergo a process called premarket approval ("PMA"). ${ }^{38}$ During the PMA process, the FDA closely investigates the product and, before approving it, must conclude that the manufacturer has adequately and reasonably demonstrated that the device is safe and effective under the conditions of use prescribed, recommended, or suggested in the proposed labeling thereof. ${ }^{39}$ The FDA determines the safety and effectiveness of a device:

(A) with respect to the persons for whose use the device is represented or intended, (B) with respect to the conditions of use prescribed, recommended, or suggested in the labeling of the device, and (C) weighing any probable benefit to health from the use of the device against any probable risk of injury or illness from such use. ${ }^{40}$

To show that a device is safe and effective, a manufacturer "must submit detailed information pertaining to the device, including all studies, reports, and other publications regarding its safety and efficacy, its component parts and functions, and the processes necessary to manufacture and package the device, as well as samples of the device, its labeling, and packaging."41 On average, the FDA spends approximately 1,200 hours reviewing the application before reaching a decision regarding its approval. ${ }^{42}$

While the general rule is that all Class III devices must undergo the rigorous PMA process, some may qualify for an exemption. One such exemption, codified at 21 U.S.C. Section $360 \mathrm{e}(\mathrm{b})(1)(\mathrm{A}-\mathrm{B})$, is for those devices which are "substantially equivalent" to a device that either (1) has already been approved through the PMA process, ${ }^{43}$ or (2) was in existence in 1976 , "in order not to stifle competition with technology existing at the time of the [1976 Medical Device Amendments]. "44 This exemption, commonly referred to as "the $510(\mathrm{k})$ process," typically subjects devices to only twenty hours of review by the FDA, instead of the approximately 1,200 hours of review typical of the PMA process. ${ }^{45}$ As one would expect, the FDA receives far more

37. 21 U.S.C. $\S 360 \mathrm{c}(\mathrm{a})(1)(\mathrm{C})(\mathrm{ii})(\mathrm{I}-\mathrm{II})(2005)$.

38. Horn, 229 F. Supp. $2 \mathrm{~d}$ at 385.

39. 21 U.S.C. $\S 360 \mathrm{c}(\mathrm{a})(1)(C)(2005) ; 21$ U.S.C. $\S 360 \mathrm{e}(\mathrm{d})(2)(A-B)(2005)$.

40. 21 U.S.C. $\$ 360 \mathrm{c}(\mathrm{a})(2)(\mathrm{A}-\mathrm{C})(2005)$.

41. Webster, 171 F. Supp. $2 d$ at 4 (quoting 21 U.S.C. $\$ 360 \mathrm{e}(\mathrm{c})(1)(2001)$ and 21 C.F.R. $\S 814(2001))$.

42. Lohr, 518 U.S. at 477.

43. 21 U.S.C. $\S 360 \mathrm{e}(\mathrm{b})(1)(\mathrm{B})(2005)$.

44. In re St. Jude Med., Inc. Silzone Heart Valves Products Liab. Litig., No. 01-1396 (JRT/FLN), 2004 U.S. Dist. LEXIS 148, at *7-8 (D. Minn. Jan. 5, 2004).

45. Horn, 229 F. Supp. 2d at 385. 
applications for medical device approval under the simplified 510(k) process than under the lengthy PMA process. ${ }^{46}$ According to a 1983 House Report, approximately 1,000 of the 1,100 Class III medical devices that had been introduced into the market since 1976 were approved through the $510(\mathrm{k})$ process. ${ }^{47}$ More recent data, submitted by the FDA in its Horn $v$. Thoratec, Corp. amicus curiae letter, reveals that this trend has continued. Of the 9,872 submissions for medical device approval in 2003 , only fifty-four proceeded via the PMA process. ${ }^{48}$

Another exemption to the PMA process is the Investigational Device Exemption ("IDE"), which, as its title suggests, is for devices that qualify as investigational under Section $360 \mathrm{j}(\mathrm{g})$ of the FDCA. ${ }^{49}$ The purpose of this exemption is "to encourage, to the extent consistent with the protection of the public health and safety and with ethical standards, the discovery and development of useful devices intended for human use and to that end to maintain optimum freedom for scientific investigators in their pursuit of that purpose." 50 These investigational devices are to be used by experts with sufficient scientific knowledge and training so that they may adequately evaluate their safety and effectiveness. ${ }^{51}$ Experts qualified to use these devices must, amongst other things, maintain thorough records and submit reports to the Secretary of Health and Human Services detailing the information gained while investigating the device..$^{52}$ Thus, in addition to the $510(\mathrm{k})$ process, the IDE exemption, created to "foster the development of useful devices," $" 53$ represents another means by which a medical device may reach the market without first being subjected to the rigorous PMA process.

Finally, and most notably for the present discussion, the 1976 Medical Device Amendments contain 21 U.S.C. Section $360 \mathrm{k}(\mathrm{a})$, the much-debated express preemption provision. This section of the FDCA obtusely declares that no state or political subdivision may establish any requirement, with respect to a medical device, that is different from, or in addition to, any requirement imposed by the FDA under the FDCA. ${ }^{54}$ Two clauses of the United States Constitution made it possible for Congress to pass Section 360k(a): the Supremacy Clause and the Dormant Commerce Clause. First, by declaring that " $[t]$ he laws of the United States ... shall be the supreme Law

46. See Gail H. Javitt, I've Got You Under My Skin-and I Can't Get Redress: An Analysis of Recent Case Law Addressing Preemption of Manufacturer Liability for Class III Medical Devices, 49 FoOD \& DRUG L.J. 553, 571 (1994).

47. Lohr, 518 U.S. at 479.

48. Horn, 376 F.3d at 167 (citing FDA Amicus Curiae Letter Br. at 12).

49. 21 U.S.C. $\$ 360 \mathrm{j}(\mathrm{g})(2005)$.

50. 21 U.S.C. $\$ 360 \mathrm{j}(\mathrm{g})(1)(2005)$.

51. 21 U.S.C. $\$ 360 \mathrm{j}(\mathrm{g})(2)(\mathrm{A})(2005)$.

52. 21 U.S.C. $\$ 360 j(g)(2)(B)($ ii) (2005).

53. Oja, 111 F.3d at 786. 1).

54. 21 U.S.C. $\$ 360 \mathrm{k}(\mathrm{a})(1)$ (2005) (for the provision's specific language, see supra note 
of the Land," 55 the Supremacy Clause provides that "state law that conflicts with federal law is "without effect," an idea clearly reflected by Section $360 \mathrm{k}(\mathrm{a})$ 's prohibition of state requirements found to differ from, or add to, federal requirements. ${ }^{56}$ Secondly, created through a judicially recognized negative inference arising from the Commerce Clause's grant to Congress of the power to regulate commerce "among the several states," Commerce Clause prohibits states from passing any laws that may unduly burden or substantially interfere with interstate commerce. ${ }^{58}$ Thus, consideration for the Dormant Commerce Clause is reflected by Section $360 \mathrm{k}(\mathrm{a})$ 's "concern that interstate commerce not be unduly burdened by numerous and varying state requirements which differ from the federal government's requirements applicable to a medical device." 59 Therefore, although the statute's proper interpretation is unclear, the incorporation of Section 360k(a) into the 1976 Medical Device Amendments to the FDCA was within the bounds of constitutionality.

Recognizing that the language of Section $360 \mathrm{k}$ (a) leaves the section's proper interpretation in question, the FDA attempted to alleviate some of the confusion by publishing 21 C.F.R. Section $808.1(\mathrm{~d})$, which provides the following:

State or local requirements are preempted only when the Food and Drug Administration has established specific counterpart regulations or there are other specific requirements applicable to a particular device under the act, thereby making any existing divergent State or local requirements applicable to the device different from, or in addition to, the specific Food and Drug Administration requirements. There are other State or local requirements that affect devices that are not preempted . . . because they are not "requirements applicable to a device" within the meaning of section 521(a) ... the act... ${ }^{60}$

The regulation goes on to include, inter alia, the following examples of state or local requirements that are not preempted, despite having the potential to affect medical devices: "(1) State or local requirements of general applicability where the purpose of the requirement relates either to other products

55. U.S. CoNST. art. VI, cl. 2.

56. Goodlin, 167 F.3d at 1370-71 (quoting Cipollone v. Liggett Group, Inc., 505 U.S. 504, $516(1992))$.

57. U.S. CoNST. art. I, $\S 8$, cl. 3.

58. Wabash, St. Louis and Pacific Ry. Co. v. Illinois, 118 U.S. 557, 571 (1886).

59. Haidak v. Collagen Corp., 67 F. Supp. 2d 21, 29-30 (D. Mass. Ct. 1999) (citing H.R. REP. No. 94-853 at 45 (1976)).

60. 21 C.F.R. $\S 808.1(d)$ (2005). 
in addition to devices ... or to unfair trade practices in which the requirements are not limited to devices;" and "(2) State or local requirements that are equal to, or substantially identical to, requirements imposed by or under the act." ${ }^{\text {"61 }}$ Despite this clarification regulation, Section $360 \mathrm{k}$ (a) has yet to be consistently interpreted. Some courts have determined that it preempts general state common law tort suits, such as Mrs. Horn's, while others have concluded that it does not.

\section{PRE-Horn Decisions Regarding THE PreEMPTIVE EFFECT OF SECTION 360K(A)}

\section{A. The Supreme Court of the United States: Medtronic, Inc. v. Lohr}

In addition to the Third Circuit Court of Appeals, a number of federal courts across the country have weighed in on Section $360 \mathrm{k}$ (a)'s preemptive effect, including the Supreme Court of the United States in the 1996 case of Medtronic, Inc. v. Lohr. ${ }^{62}$ In Lohr, the Court was faced with the task of determining whether Section $360 \mathrm{k}$ (a) preempted state common law claims of negligence and strict liability against the manufacturer of a faulty pacemaker, approved by the FDA through the streamlined Section 510(k) process due to its substantial equivalency to another, previously-approved pacemaker. ${ }^{63}$ To aid the analysis, the Court developed a two-pronged test. First, it had to determine whether there was a federal requirement "applicable to the device" in question. Second, the court then had to ask whether a state requirement existed "with respect to" the device that was "different from, or in addition to" the federal requirement(s) ${ }^{64}$ Upon applying this two-step inquiry, the Court concluded, in a fractured 5-4 plurality decision, ${ }^{65}$ that Lohr's common claims were not preempted by Section $360 \mathrm{k}(\mathrm{a})$ as neither of the two requirements were met. ${ }^{66}$ Writing for the Court, Justice Stevens declared:

61. 21 C.F.R. § 808.1(d)(1-2) (2005).

62. Medtronic, Inc. v. Lohr, 518 U.S. 470 (1996).

63. See id. (although the complaint was initially dismissed in the federal district court, the court of appeals reversed with regard to the negligent design claims before the case ultimately came before the Supreme Court).

64. Lohr, 518 U.S. at $498-500$ (cited in Oja, 111 F.3d at 788).

65. See, Oja, 111 F.3d at $788 \mathrm{n} .3$ (the Court's decision was delivered in seven parts, of which parts I, II, III, V, VII form the plurality opinion. For these five parts, Justice Stevens was joined by Justices Kennedy, Souter, Ginsburg, and Breyer. For parts IV and VI, Stevens was joined only by Kennedy, Souter, and Ginsburg, while Breyer wrote a separate opinion, concurring in part and concurring in the judgment. Justice $O^{\prime}$ Connor filed an opinion concurring in part and dissenting in part, which was joined by Justices Scalia and Thomas and Chief Justice Rehnquist).

66. Lohr, 518 U.S. at 500-01. 
Although we do not believe that this [ $\$ 360 \mathrm{k}$ (a) and 21 C.F.R. $\S 808.1(\mathrm{~d})]$ statutory and regulatory language necessarily precludes "general" federal requirements from ever pre-empting state requirements, or "general" state requirements from ever being pre-empted, ... it is impossible to ignore its overarching concern that pre-emption occur only where a particular state requirement threatens to interfere with a specific federal interest. State requirements must be "with respect to" medical devices and "different from, or in addition to," federal requirements. State requirements must also relate "to the safety or effectiveness of the device or to any other matter included in a requirement applicable to the device," and the regulations provide that state requirements of "general applicability" are not pre-empted except where they have "the "effect of establishing a substantive requirement for a specific device." $" 67$

Although the Court's holding clearly confirmed that Section $360 \mathrm{k}$ (a) does not preempt state common law suits involving medical devices that have been approved through the Section 510(k) process, the opinion was "fractured in an all but irreconcilable manner over the extent to which section 360k(a) would ever preempt a general state common law tort claim" involving a medical device that was approved through the rigorous PMA process. ${ }^{68}$ Nonetheless, the Court's language in part V of the opinion hints that, in addition to preempting claims involving Section $510(\mathbf{k})$-approved devices, Section $360 \mathrm{k}(\mathrm{a})$ also does not preempt state common law claims involving PMA-approved medical devices. In that portion of its opinion, the Court stated that "when Congress enacted [Section] $360 \mathrm{k}$, it was primarily concerned with the problem of specific, conflicting state statutes and regulations rather than the general duties enforced by common-law actions." ${ }^{39}$ As it would be "rare indeed for a court hearing a common-law cause of action to issue a decree that has 'the effect of establishing a substantive requirement for a specific device, ${ }^{, " 70}$ Section $360 \mathrm{k}$ (a) was not designed to preempt common law claims. Moreover, when commenting on the proper interpretation of the word "requirement," as it is used in Section $360 \mathrm{k}(\mathrm{a})$, Stevens again hinted that Section 360k(a) does not preempt general state common law claims involving PMA-approved devices by stating that "its focus is device-specific enactments

67. Id. at 500 (quoting 21 U.S.C. $\S 360 \mathrm{k}$ (a) (2004) and 21 C.F.R. $\S 808.1$ (d) (1995)).

68. Goodlin, 167 F.3d at 1371.

69. Lohr, 518 U.S. at 489. Later in his opinion, Justice Stevens expounds on this idea by stating that " $[t]$ hese general obligations are no more a threat to federal requirements than would be a state-law duty to comply with local fire prevention regulations and zoning codes, or to use due care in the training and supervision of a work force." Id. at 501-502.

70. Id. at 502-503 (citing 21 C.F.R. $\$ 808.1$ (d)(6)(ii) (1995)). 
of positive law by legislative or administrative bodies, not the application of general rules of common law by judges and juries."71

In addition to Justice Stevens's plurality opinion, Justice Breyer's concurring opinion provided some insight into the Court's stance on the boundaries of Section 360k(a)'s preemptive reach. While opining that the PMA process may "sometimes preempt a state-law tort suit,"72 Justice Breyer illustrated his understanding of the issue by providing the following hypothetical aimed at conveying his conception of the statute's use of "requirement:" State $\mathrm{X}$ has a regulation requiring hearing aid wires to be one inch in length, but the federal, PMA-imposed regulation specifies that hearing aid wires be two inches in length. As State X's regulation regarding the length of hearing aid wires represents an affirmative, substantive, devicespecific enactment, it should be preempted by the federal requirement pursuant to Section $360 \mathrm{k}(\mathrm{a}) .^{73}$ Thus, Justice Breyer opined that Section $360 \mathrm{k}$ (a) should only work to preempt those state requirements that are specifically created for a particular FDA-approved medical device. ${ }^{74}$

Based on these portions of the Lohr opinion, it is likely that, if given the opportunity, the Supreme Court would conclude that common law tort claims involving PMA-approved devices survive Section $360 \mathrm{k}(\mathrm{a})$ 's preemption language, just as it did with common law tort claims involving devices approved through the abbreviated Section $510(\mathrm{k})$ process. In both cases, the common law state claims impose generally applicable duties, rather than the device-specific requirements that the Court has decided Section 360k(a) is aimed at preempting.

\section{B. Circuit Court Decisions}

Because the Supreme Court's decision in Lohr was primarily concerned with Section 360k(a)'s preemptive effect on state claims involving medical devices approved via the speedy Section $510(\mathrm{k})$ process, the circuit courts of appeals have been on their own to determine the extent of Section $360 \mathrm{k}(\mathrm{a})$ 's preemptive reach with regard to state claims involving PMA-approved devices, which has resulted in a confusing circuit split. For example, a majority of the circuit courts, including the First, Second, Third, Fifth, Sixth, Seventh, Eighth, and Ninth, have concluded that general state tort claims are preempted. ${ }^{75}$ These courts have generally determined that state common law

71. Id. at 489.

72. Id. at 503 (Breyer, J., concurring).

73. Id. at 504.

74. Id.

75. See Horn v. Thoratec Corp, 376 F.3d 163 (3d Cir. 2004) (involving a heart pump); Martin v. Medtronic, Inc., 254 F.3d 573 (5th Cir. 2001) (involving a pacemaker); Brooks v. Howmedica, Inc., 273 F.3d 785 (8th Cir. 2001) (involving bone cement); Kemp v. Medtronic, Inc., 231 F.3d 216 (6th Cir. 2000) (involving a pacemaker); Martin v. Teletronics Pacing 
claims should be preempted by Section $360 \mathrm{k}(\mathrm{a})$ because they represent an attempt to impose requirements on medical devices that are different from, or in addition to, the federal, PMA-imposed requirements. In arriving at this determination, these circuits have relied on the following two controversial assumptions: 1) the PMA process imposes specific requirements on approved medical devices with which state requirements could conflict or add; and 2) general state common law tort claims impose specific requirements on FDA ápproved medical devices that are different from, or in addition to, the federal PMA requirements. ${ }^{76}$

On the other hand, the Fourth, Tenth, and Eleventh Circuit Courts have concluded that state common law tort claims are preempted by Section $360 \mathrm{k}(\mathrm{a})$, but for different reasons. ${ }^{77}$ For example, in a 1997 case involving a woman's negligent failure to warn claim, brought after she sustained injuries caused by a poorly manufactured prosthetic hip replacement system, the Tenth Circuit decided that the state common law claims were not preempted because they did not impose specific requirements on the device. ${ }^{78}$ In reaching this conclusion, the court declared:

[T] he duties imposed by [plaintiff's] negligent failure to warn claim do not constitute positive enactments of state law sufficient to constitute a state requirement developed "with respect to" a medical device. . . [G]eneral dut[ies . . . are] "not the kind[] of requirement[s] []that Congress and the FDA feared would impede the ability of federal regulators to implement and enforce specific federal requirements." 79

The Eleventh Circuit has arrived at a similar result via a different route, as evidenced by its 1999 decision in Goodlin v. Medtronic, Inc. In that case,

Systems, Inc., 105 F.3d 1090 (6th Cir. 1997) (involving an implantable cardioverterdefibrillator-demand pacemaker); Mitchell v. Collagen Corp., 126 F.3d 902 (7th Cir. 1997) (involving collagen-based injection treatments); Papike v. Tambrands Inc., 107 F.3d 737 (9th Cir. 1997) (involving tampons); Talbott v. C.R. Bard, Inc., 63 F.3d 25 (1st Cir. 1995) (involving a heart catheter balloon); Becker v. Optical Radiation Corp., 66 F.3d 18 (2d Cir. 1995) (involving an intraocular lens); Michael v. Shiley, Inc., 46 F.3d 1316 (3d Cir. 1995) (involving a heart valve).

76. Most likely, these assumptions are the courts' response to the following two-prong inquiry suggested by the Supreme Court in Lohr: 1) is the federal requirement "applicable to the device" in question and 2) is the state requirement "with respect to" a medical device, and is it "different from, or in addition to," a federal requirement? Lohr, 518 U.S. at 486 (quoting 21 U.S.C. § 360k (1995)). See also Scandaglia \& Tully, supra note 33, at 257.

77. Sanders v. Optical Radiation Corp., No. 95-1967, 1996 U.S. App. LEXIS 18887 (4th Cir. July 30, 1996) (involving an implantable intraocular lens); Oja, 111 F.3d 782 (10th Cir. 1997)(involving a prosthetic hip replacement system); Goodlin, 167 F.3d 1367 (11 th Cir. 1999) (involving a pacemaker).

78. Oja, $111 \mathrm{~F} .3 \mathrm{~d}$ at 789.

79. Id. (quoting Lohr, 518 U.S. at 501) (alterations in original). 
the court was asked to determine the preemptive effect of Section $360 \mathrm{k}(\mathrm{a})$ on a woman's state common law tort claims of negligent design and strict product liability, brought after she underwent open-heart surgery to replace a pacemaker manufactured by the defendant. The court focused on the PMA process' lack of specificity by opining the following with regard to the term "requirement:" "[W]ithin] section 360k, Congress referred to a requirement as something a state or political subdivision could 'establish,' which appears to contemplate the state's creation of and, thus, identification of some thing ... [The word] 'requirement' . . contemplate[s] the imposition of some identifiable precondition that applies to the device in question." 80 Accordingly, the court concluded that "the FDA's approval of a medical device pursuant to the PMA process, standing alone, imposes no specific federal requirement applicable to [the pacemaker] and, therefore, has no preemptive effect under section $360 \mathrm{k}$ (a) of the MDA." ${ }^{\text {"81 }}$ Thus, the woman's state common law tort claims survived preemption.

Finally, in Sanders v. Optical Radiation Corp., the Fourth Circuit faced a situation in which the plaintiff brought state common law claims of negligence, strict liability, lack of informed consent, breach of warranty, and negligence per se after he was allegedly injured by defendant's implantable intraocular lenses. ${ }^{82}$ The court concluded that the plaintiff's state common law claims were not preempted by Section $360 \mathrm{k}(\mathrm{a})$, hinging its decision on the fact that, because the device was federally approved through the Investigational Device Exemption ("IDE"), no specific federal requirements had been imposed upon the device with which a state requirement could possibly conflict. ${ }^{83}$ The case was ultimately remanded to the district court for consideration consistent with the Fourth Circuit's conception of Section $360 \mathrm{k}(\mathrm{a})$ 's preemptive reach. ${ }^{84}$

\section{INADEQUACY OF THE ELEVENTH CIRCUIT'S APPROACH}

As previously suggested, the Tenth and Eleventh Circuit approaches to interpreting Section $360 \mathrm{k}$ (a) represent the two prevailing schools of thought among those who believe that state common law tort claims should not be preempted. Nevertheless, although both interpretations reach a similarly desirable goal, the reasoning employed by the Eleventh Circuit in reaching that goal is difficult to accept. According to the court, state common law claims should not be preempted because the supposed federal requirements,

80. Goodlin, 167 F.3d at 1374.

81. Id. at 1382. For a more complete explanation of the reasoning behind the Eleventh Circuit's decision that the PMA process does not impose specific requirements, see Reiders, supra note 32 and Part IV of this note.

82. Sanders, 1996 U.S. App. LEXIS 18887.

83. Id. at *3-4.

84. Id. at *5. 
imposed through the PMA process, are not requirements at all and, therefore, are incapable of conflicting with state-imposed requirements. ${ }^{85}$ Neither the FDA's review nor its approval via the PMA process imposes any "ascertainable requirement" on a device. ${ }^{86}$ In support of its opinion, the court added that, in the typical PMA process review, the FDA does not promulgate any "regulation, order, or any other statement of its substantive benchmark."87

The Eleventh Circuit is not alone in its opinion that the PMA process does not impose specific requirements on devices with which state requirements could possibly conflict. For example, the Federal District Court of the District of Columbia echoed the Goodlin holding when it declared that, "[t]he fact that the PMA process requires certain information and mandates certain procedures from manufacturers does not transform the PMA process itself into a specific federal requirement which triggers preemption and protects a manufacturer from suit."88 Moreover, a New York state appellate court held in Sowell v. Bausch \& Lomb, Inc. that the PMA process does not represent a specific federal requirement due to its failure to impose a specific standard on the optical device at issue. ${ }^{89}$ According to these courts, Section $360 \mathrm{k}$ (a) does not stand in the way of state common law tort claims because the FDA-approval process fails to impose specific requirements.

Although the preceding view pursues a desirable goal (non-preemption of state tort claims involving medical devices), the reasoning offered in arriving at that goal is problematic. As the typical PMA process involves approximately 1,200 hours of review, "during which FDA reviews the device's clinical data; preclinical test results; proposed labeling; components; and the methods, controls, and facilities used in the manufacturing and processing of the device,"91 it is difficult to accept the proposition that this process imposes no specific requirements on medical devices. On the contrary, the thoroughness of the PMA review, coupled with the FDA's ability to deny the PMA application for failure to comply with agency regulations, demonstrates that the PMA process inevitably leads to the imposition of specific requirements upon the device at issue. This view is supported by a number of courts, including the Seventh Circuit Court of Appeals, which, in quoting the Supreme Court of Rhode Island, noted that "the PMA process 'involved a review of all the ingredients, components, manufacturing methods, and labeling to be used in conjunction with the [medical device]"' and is,

85. Goodlin, 167 F.3d at 1382.

86. Id. at 1375 .

87. Id. (cited by Rieders, supra note 32, at 1192).

88. Lakie v. SmithKline Beecham, 965 F. Supp. 49, 54 (D.C. 1997) (italics in original); see also Webster, 171 F. Supp. 2d at 11 (D.C. 2001) (explaining that "even if the PMA process is much more rigorous, time-consuming, and expensive, this does not mean that the approval imposes 'specific requirements."'); Rieders, supra note 32, at 1191-95.

89. Sowell v. Bausch \& Lomb, Inc., 656 N.Y.S. 2d 16, 20 (N.Y. App. Div. 1997).

90. Lohr, 518 U.S. at 477.

91. Scandaglia and Tully, supra note 33, at 257. 
therefore, a "specific federal regulation." The Third Circuit also maintains this view, which is demonstrated by its declaration in Horn that "[ $\mathrm{t}]$ here is no doubt that, as a practical reality, the PMA process imposed requirements that were specifically applicable to the [device] ....993 The court noted that this determination was informed by the PMA process' imposition of "mandatory conditions" on the device, "created through a decades-long process of correspondence, clinical testing and device alteration-pertaining to the [device]'s manufacturing, packaging, storage, labeling, distribution and advertising."94 Thus, in light of these considerations, it is difficult to dispute that the PMA process imposes specific requirements on medical devices. Accordingly, it is erroneous for courts, such as the Eleventh Circuit, to conclude that state tort claims are not preempted by Section $360 \mathrm{k}(\mathrm{a})$ simply because the PMA process does not impose specific federal requirements with which state requirements could possibly conflict.

\section{A CALL FOR THE UNIFORM ADOPTION OF THE TENTH CIRCUIT'S APPROACH}

The present disagreement among the Circuit Courts regarding the proper interpretation of Section $360 \mathrm{k}$ (a) needs to be resolved so that consumers who have been injured by medical devices may have clear notice regarding the extent of potential recourse available to them through state common law claims. It is grossly unfair that a consumer who has been injured by a medical device in Colorado (Tenth Circuit) may obtain a remedy from the device's manufacturer, while a consumer, such as Mrs. Horn, who has been injured by a medical device in Pennsylvania (Third Circuit) is left empty handed. To resolve this inequity, all courts should follow the reasoning employed by Judge Fuentes and adopt the Tenth Circuit's approach that state common law tort claims involving medical devices are not preempted by Section $360 \mathrm{k}(\mathrm{a})$ because they do not impose specific requirements that differ from, or add to, federally imposed requirements.

As previously discussed, the Tenth Circuit arrived at this conclusion when it was given the task of determining whether Section $360 \mathrm{k}(\mathrm{a})$ preempted a woman's state common law negligent failure to warn claim, brought after she sustained injuries caused by the defendant's cementless hip replacement

92. Mitchell, 126 F.3d at 911 (quoting Fry v. Allergan Medical Optics, 695 A.2d 511 (R.I. 1997)); see also Martin, 254 F.3d 573; Kemp, 231 F.3d at 216; and Scandaglia and Tully, supra note 33, at 259258 (arguing that "in reviewing and approving the design, components, manufacturing process, and labeling of a device during the intensive PMA process, [the] FDA, through its approval or rejection of the device, is imposing specific requirements on that device related to each of those areas.").

93. Horn, 376 F.3d at 170.

94. Id. (italics omitted). 
system. ${ }^{95}$ Following Lohr's two-pronged test, the court began its analysis by looking at the federal process by which the device was approved in order to determine whether it imposed specific requirements upon the device. This inquiry was quickly resolved in the affirmative due to the record's indication that the FDA had, in fact, imposed a specific labeling requirement on the hip replacement system during its approval process. ${ }^{96}$ The court then shifted its focus to the plaintiff's common law negligent failure to warn claim and asked whether it constituted a state requirement, developed with respect to the hip replacement system, which added to, or differed from, the specific federal labeling requirement. ${ }^{97}$ Recognizing that the plaintiff's state common law claim was "predicated upon a general duty applicable to every manufacturer 'to inform users and purchasers of potentially dangerous items of the risks involved in their use," $" 98$ the court found the state claim to impose only a generally applicable requirement on the device, and thus resolved the second query in the negative. ${ }^{99}$ The state claim was not specifically developed with respect to the device in question and, therefore, should not be preempted by Section $360 \mathrm{k}(\mathrm{a}) .^{100}$ In a particularly notable portion of its opinion, the court ensured the clarity of its decision with the following language: "the standard of care governing [plaintiff's] negligent failure to warn claim is not the type of device-specific requirement that would threaten. . . federal interests." 101

The Tenth Circuit has taken the correct approach in evaluating Section $360 \mathrm{k}(\mathrm{a})$ 's preemptive effect on state common law tort claims. When a plaintiff brings a state common law tort claim alleging negligence in the manufacturing of a medical device, for example, their complaint will typically consist, inter alia, of the following four general elements: 1) the manufacturer had a general duty to use good care in manufacturing the device; 2) the manufacturer breached that duty; 3 ) the manufacturer's breach caused the

95. Oja, $111 \mathrm{~F} .3 \mathrm{~d}$ at 789. At this point, a brief discussion of the history of the FDA's approval of the cementless hip replacement system is in order. Initially, the device was approved by the FDA through the expedited Section $510(\mathrm{k})$ process when used with bone cement. Soon thereafter, the manufacturer of the device submitted an IDE application to the FDA for use of the device without cement. The IDE application was eventually approved, but not before the plaintiff was implanted with the device. (Thus, the Third Circuit was mistaken in Horn when, during its discussion of Oja, it appeared to claim otherwise. See Horn, 376 F.3d at $169, \mathrm{n} .11$ ). A few years after IDE approval, the device manufacturer applied to the FDA for permission to market the cementless device. The FDA approved the application, classifying the device as Class III. One year later, the FDA reclassified the cementless device as Class II. Oja, 111 F.3d at 786-87. This information is peripheral to the present discussion, however, since the Tenth Circuit's decision against preemption hinged on the lack of specificity of the state common law tort claims, rather than on the specificity, or lack thereof, of the federal requirements.

96. Oja, 111 F.3d at 789.

97. Id.

98. Id. (quoting Medtronic, Inc. v. Lohr, 518 U.S. at 500).

99. Id.

100. Id.

101. Id. (citing Medtronic, Inc. v. Lohr, 518 U.S. at 500-01). 
plaintiff's injuries; and 4) the plaintiff can demonstrate real injury. ${ }^{102}$ As one can plainly see, a claim of this nature merely involves the imposition of the general duty to use good care in manufacturing; it does not involve the imposition of a specific state "requirement," developed "with respect to" a medical device. ${ }^{103}$ Thus, there is nothing that could possibly differ from, or add to, any federal requirement applicable to the device. This holds true for many state common law tort claims, which involve the imposition of the same kind of general duties. These claims involve a level of generality that should clearly remove them from the gambit of specific state requirements that Section $360 \mathrm{k}(\mathrm{a})$ is aimed at preempting. ${ }^{104}$. As Judge Fuentes wrote in his dissenting opinion in Horn, claims such as negligence, strict liability, breach of warranty, and failure to warn are all general common-law tort claims that were not crafted specifically to govern medical devices, and so they are or they should be excepted from the scope of Section $360 \mathrm{k}(\mathrm{a}) .^{105}$ This conclusion is consistent with Congressional intent and furthers public policy goals.

\section{A. Congressional Intent}

As Justice Stevens declared in Part III of his Lohr opinion, " the purpose of Congress is the ultimate touchstone' in every pre-emption case."106 Therefore, a determination of the proper interpretation of Section $360 \mathrm{k}$ (a) should begin with a close look at Congressional intent when it passed this portion of the Medical Device Amendments. Did Congress intend to shield an entire industry from responsibility for the injuries caused by faulty medical devices, or did it merely intend to prevent state legislatures from imposing substantive requirements on specific, federally approved medical devices? As it is unlikely that Congress would have intended to shield an entire industry from liability, the only reasonable answer to this query is that, in passing Section $360 \mathrm{k}(\mathrm{a})$, Congress merely wanted to prevent states from imposing substantive requirements on specific medical devices that conflict with federally imposed requirements. Indeed, Justice Stevens echoed this conclusion when he opined that it was unpersuasive and implausible to argue that Congress would have intended to preclude "state courts from affording state consumers any protection from injuries resulting from a defective medical device."107 Any conclusion to the contrary would "have the perverse

102. 57A. AM. JUR. 2D Negligence $\S 71$ (2005).

103. 21 U.S.C. $\S 360 \mathrm{k}(\mathrm{a})(1)(2005)$.

104. See Lohr, 518 U.S. at 500 (Supreme Court opining that [21 C.F.R. $\S 808.1(d)$ ] "provide[s] that state requirements of 'general applicability' are not pre-empted except where they have 'the effect of establishing a substantive requirement for a specific device"').

105. Horn, 376 F.3d at 180 (Fuentes, J., dissenting).

106. Lohr, 518 U.S. at 485 (quoting Retail Clerks v. Schermerhorn, 375 U.S. 96, 103 (1963)).

107. Id. at 487 . 
effect of granting complete immunity from design defect liability to an entire industry that, in the judgment of Congress, needed more stringent regulation in order 'to provide for the safety and effectiveness of medical devices intended for human use." 108 The legislative history of the MDA supports this conclusion as " $[t]$ here is . . nothing in the hearings, the Committee Reports, or the debates suggesting that any proponent of the legislation intended a sweeping pre-emption of traditional common-law remedies against manufacturers and distributors of defective devices."109

There are a number of other clues suggesting that Congress could not have intended Section $360 \mathrm{k}$ (a) to have the broad preemptive effect embraced by a majority of the Circuit Courts. For example, in 1994, Congress attempted to enact the Product Liability Fairness Act. ${ }^{110}$ This proposed act sought to create federal standards of product liability which, therefore, "would have prevented private litigants from recovering punitive damages from the manufacturers of medical devices in cases where the . . device . . . was subject to pre-market approval." "'11 If Congress had intended Section 360k(a) to preclude all state common law claims, this bill probably would not have been proposed. Indeed, the Eleventh Circuit declared the following:

[I] $\mathrm{f}$ the 1976 Congress truly had intended section $360 \mathrm{k}(\mathrm{a})$ of the MDA to preempt all or most state law claims involving PMA approved devices, then there would have been no need for the 1994 Congress to include those devices in its proposed solution to the more general travails of product liability law. ${ }^{112}$

Other evidence that Congress probably did not intend Section $360 \mathrm{k}(\mathrm{a})$ to preempt all state tort claims involving medical devices exists in the fact that "the first reported decisions on the industry's attempts to assert federal preemption of state product liability claims for devices subject to the FDA's approval regimes did not appear until 1991, fifteen years after Congress passed the MDA." 13 According to the Eleventh Circuit, "it seems unlikely that the industry would have ignored its immunity under the MDA for so long after the statute's enactment if Congress, in fact, had intended to provide immunity in 1976."114

108. Id. (quoting 90 Stat. 539 (preamble to Act)).

109. Id. at 491.

110. S. 687, 103d Cong. $\$ 203$ (1994) (cited in Goodlin, 167 F.3d at 1379-80).

111. Goodlin, 167 F.3d at 1380 (citing S. 687, 103d Cong. § 203 (1994)).

112. Id.

113. Id. at 1381 (citing Slater v. Optical Radiation Corp., 756 F. Supp. 370 (N.D. Ill. 1991)).

114. Id. at 1381 . 


\section{B. Statutory Construction}

The specific language that Congress chose to include in Section $360 \mathrm{k}(\mathrm{a})$ also supports the conclusion that Congress probably did not intend to preempt all state common law tort claims involving federally-approved medical devices. Specifically, Congress used the word "requirement," and chose to modify it with the phrase "with respect to a device."115 Even at first blush, most readers would probably conclude that this particular word order conveys the idea that Congress was intending to preempt only those state requirements that were created specifically for ("with respect to") a particular device, rather than general requirements, such as good care in manufacturing, that are applicable to a host of devices. The fact that Congress chose to place the words in this particular order suggests that the only requirements intended for preemption are those which specifically relate to a particular device. Justice Stevens reflected this understanding when he declared in Lohr that "requirement" is focused on device-specific enactments of positive law by legislative or administrative bodies, not the application of general rules of common law by judges and juries. ${ }^{116}$ Elsewhere in his opinion, Justice Stevens again echoes this sentiment by describing the appropriate preemption situation as one involving a "particular state requirement."117 This interpretation is also supported by Justice Breyer's aforementioned hearing aid wire hypothetical, in which he explains that preemption is only appropriate if the state requirement in question is as device-specific as the imposition of a mandatory length for hearing aid wires. ${ }^{118}$ In that example, the requirement is clearly developed "with respect to" particular medical devices (hearing aids) and is deserving of preemption. The general duties imposed by state common law tort claims do not fall within this category. Thus, as state common law claims typically impose general duties of good care in manufacturing, they probably do not represent the affirmative imposition of substantive state law that Congress intended to preempt when it chose the words "requirement" and "with respect to a device."

The Tenth Circuit took this position when it observed that negligence principles do not constitute requirements developed "with respect to' a medical device," and even went on to specifically state that the general duties imposed by negligence actions are " not the kind [] of requirement[s] [] that Congress and the FDA feared would impede the ability of federal regulators to implement and enforce specific federal requirements." 119 Moreover, it is

115. 21 U.S.C.S. $\$ 360 \mathrm{k}(\mathrm{a})(2005)$. "[N]o State ... may establish or continue in effect with respect to a device intended for human use any requirement ....") (emphasis added).

116. Lohr, 518 U.S. at 490.

117. Id. at 500 (emphasis added).

118. Id. at 504 .

119. Oja, 111 F.3d at 789 (quoting Lohr, 518 U.S. at 501). 
feasible to argue that even the FDA entertained this view when it issued 21 C.F.R. Section 808.1(d), entitled "Exemptions From Federal Preemption of State and Local Medical Device Requirements." In that regulation, the agency states that Section $360 \mathrm{k}(\mathrm{a})$ appropriately preempts "[s]tate or local .. . specific requirements applicable to a particular device," and then goes on to include the following example of what that phrase does not include: "State or local requirements of general applicability where the purpose of the requirement relates either to other products in addition to devices ... or to unfair trade practices in which the requirements are not limited to devices."120 This language can easily be taken for the proposition that the general requirements imposed by state common law claims are not preempted by Section 360k(a) because they are applicable in a number of situations to a number of different products, not simply in situations involving specific medical devices. The FDA again revealed this understanding when it published 45 Federal Register 67,321. Within this regulation, the FDA discussed California's standard for prescription ophthalmic devices as an example of the type of state requirement that is preempted by Section $360 \mathrm{k}(\mathrm{a}){ }^{121}$ As California's prescription standard represented a very specific state requirement, it is reasonable to infer that the FDA published this ruling, at least in part, to demonstrate that Section 360k(a) is intended to preempt device-specific requirements, not the general requirements imposed by state common law claims.

In addition to the "requirement" and "with respect to" language, Congress also revealed its intent to avoid preemption of state common law tort claims through the use of the phrase "different from, or in addition to."122 As the duties imposed through state common law tort claims typically seek to ensure good care and safety, it is difficult to comprehend how these actions could be "different from, or in addition to" federally-imposed requirements. In fact, this objective is entirely consistent with, rather than "different from, or in addition to," the purpose behind the federal requirements. Just as state common law tort claims impose the duties of good care and safety, the goal of the federal requirements is to ensure the safety and effectiveness of medical devices intended for human use. Accordingly, state common law tort claims should survive preemption because they are not "different from, or in addition to," the federally-imposed requirements. Based on a close look at the language that Congress chose to use in Section 360k(a), courts should

120. 21 C.F.R. § 808.1(d)(1) (2005).

121. Medical Devices; California Application for Exemption From Federal Preemption of State Medical Device Requirements, 45 Fed. Reg. 67,321, 67,323 (Oct. 10, 1980) (to be codified at 21 C.F.R. pt. 808).

122. 21 U.S.C. $\$ 360 \mathrm{k}(\mathrm{a})(1)(2005)$ (" $[\mathrm{N}]$ o State or political subdivision of a State may establish ... with respect to a device intended for human use any requirement-(1) which is different from, or in addition to, any requirement applicable under this chapter to the device...") (emphasis added). 
interpret the statute to preempt only specific requirements created to apply to particular devices.

\section{Presumption Against Federal Preemption of State Regulations}

The uniform adoption of the Tenth Circuit approach is also supported by the Supreme Court's observation that, when engaging in a preemption analysis such as the one at hand, courts must not only be guided by congressional intent, but must also understand that there is a presumption against federal preemption of a state regulation. ${ }^{123}$ Thus, even if state common law claims are deemed to impose some requirements upon medical devices, courts should be hesitant to conclude that they are federally preempted. Indeed, "[p]reemption is disfavored in areas of historic importance to the states' police powers -- areas such as public health and safety." 124 As the state tort claims at issue seek redress for harm caused to health and safety, courts should maintain a presumption against federal preemption of such claims.

\section{Public Policy}

Important policy considerations also support the view that state common law claims should not be preempted. As the purpose of the 1976 Medical Device Amendments was "to provide for the safety and effectiveness of medical devices intended for human use," PMA should be seen as the floor, not the ceiling. This is the precise reason why the Third Circuit's declaration in Horn, that any finding other than total preemption of all Mrs. Horn's state common law claims would "stand' as an obstacle to the accomplishment and execution of the objective of the safety and effectiveness of the HeartMate," ${ }^{126}$ is counter-intuitive and unpersuasive. Rather, a reasonable person would likely conclude that allowing Mrs. Horn to bring her state common law claims would serve as a positive contribution to accomplishing the PMA process' objective of ensuring the safety and effectiveness of the HeartMate. ${ }^{127}$ Judge Fuentes reflected this sentiment in

123. Lohr, 518 U.S. at 484-85.

124. In re St. Jude Med., Inc. Silzone Heart Valves Products Liab. Litig., No. 01-1396 (JRT/FLN), 2004 U.S. Dist. LEXIS 148 at *16 (D. Minn. Jan. 5, 2004) (citing Kemp, 231 F.3d at 222); see also Scandaglia \& Tully, supra note 33, at 253 (explaining that "[i]n applying the preemption doctrine, courts assume that Congress did not intend to displace the States' police powers, unless it is 'the clear and manifest purpose of Congress' to accomplish this result.") (citing Lohr, 518 U.S. 485 and Jones v. Rath Packing Co., 430 U.S. 519, 525 (1977)).

125. Oja, 111 F.3d at 786 (quoting Pub. L. No. 94-295, 90 Stat. 539 (1976)).

126. Horn, 376 F.3d at 179 (quoting Geier v. Am. Honda Motor Co., 529 U.S. 861,873 (2000)).

127. See Milkiewicz v. Baxter Healthcare Corp., 963 F. Supp. 1150, 1156-1157 (M.D. Fla. 1996) (concluding that "state-law claims are not preempted under Section $360 \mathrm{k}$ (a) to the extent that they seek to enforce requirements established by the FDA as a result of the PMA process."). 
his dissenting opinion in Horn stating: "I believe that allowing common-law liability would simply have the effect of encouraging [defendant] and other device manufacturers to go above and beyond FDA standards, and this effect would clearly not contradict the MDA's purpose of enhancing medical device safety."128 Otherwise, medical device manufacturers, such as Thoratec Corporation, are shielded from common law liability and, therefore, do not receive the requisite negative incentive to swiftly correct problems with their devices in order to make them safer and more effective. Perhaps Judge Ferguson, of the Ninth Circuit Court of Appeals, put it best when he declared that "[p]remarket approval is supposed to benefit consumers, not create a rose garden, free from liability, for manufacturers." 129

A final policy concern to consider is the cost-shifting effects that will result if Section $360 \mathrm{k}(\mathrm{a})$ is held to preempt state common law actions against manufacturers of medical devices approved through the PMA process. By shielding medical device manufacturers from liability, courts would merely be shifting the responsibility of paying the medical costs associated with the injuries caused by faulty medical devices to other entities, such as the injured parties themselves or insurance companies. While insurance companies may be able to bear this burden by raising their rates, individuals will typically be forced to incur substantial debt in order to pay their hospital bills. In its worst form, this unfortunate financial position could force individuals, who have likely suffered severe physical hardships, to sell their belongings or declare bankruptcy in order to satisfy their enormous debt.

In addition to injured parties and insurance companies, doctors would be negatively affected if all state common law claims against medical device manufacturers were deemed preempted. Once an injured individual realizes that he cannot recover from the manufacturer of the medical device that caused his injuries, it is likely that he will attempt to bring a malpractice action against the surgeon who implanted the device in an effort to simply recover some type of recompense for his injuries. This, in turn, will cause an unaffordable increase in many doctors' malpractice insurance rates. Present malpractice insurance rates already cause a great number of doctors to forego careers as practicing physicians, and this problem will be exacerbated if injured parties cannot recover from medical device manufacturers. Incidentally, it was high malpractice insurance rates that caused Dr. Benjamin Sun, Mr. Horn's cardiothoracic surgeon, to leave private practice and join the faculty of a medical school located in another state. ${ }^{130}$

128. Horn, 376 F.3d at 180.

129. Kennedy v. Collagen Corp., 67 F.3d at 1453, 1460 (9th Cir. 1995), cert. denied, 518 U.S. 1033 (1996).

130. Disappearing Docs, Politically Active Physicians Association . . Home of the Fighting Docs, available at $\mathrm{http} / / \mathrm{www}$.fightingdocs.com/main/disappearing_docs.html. (last visited March 9, 2005). 
In sum, the view that Section 360k(a) preempts state common law tort claims contravenes Congressional intent and disregards many important public policy considerations. Accordingly, courts should uniformly adopt the Tenth Circuit's opinion that Section 360k(a) only preempts state claims involving specific requirements developed for particular, federally-approved medical devices, rather than general state tort claims that are applicable in many circumstances to any number of medical devices.

\section{THE THIRD CIRCUIT'S UNDUE DEFERENCE TO THE FDA's AMICUS CURIAE BRIEF IN HORN}

Setting the topic of Section 360k(a)'s proper interpretation aside, the focus of the following discussion will turn to evaluating the propriety, or lack thereof, of the Third Circuit's heavy reliance on the amicus curiae brief submitted by the FDA in Horn. Admittedly, the court afforded an extremely high degree of deference to the FDA's opinion in reaching its conclusion that Mrs. Horn's state common law tort claims were preempted by Section $360 \mathrm{k}(\mathrm{a}){ }^{131}$ Signs of this substantial reliance are apparent throughout the court's opinion. For example, the court deferred to the FDA's summary of Mrs. Horn's claims in footnote five, ${ }^{132}$ detailed the FDA's comparison of the Section 510(k) and PMA processes in footnote six, ${ }^{133}$ and devoted two entire subsections to the FDA's position in parts (1)(B) and (2)(B) of its opinion. ${ }^{134}$

For purposes of the present discussion, the most consequential deference the court made to the FDA's position occurred in part (2)(B) of the opinion. Here, the court repeatedly used the FDA's amicus brief to support its conclusion that state common law tort suits impose specific requirements on a device that could potentially differ from, or add to, federally-imposed requirements. Specifically, at the outset of this portion of its opinion, the court sets forth that "[t] he FDA conceives of Horn's state common law claims as imposing a 'requirement' which is 'different' from that imposed by the FDA in the PMA process, and thus requiring preemption." 135

In the very next paragraph, the court again cites the FDA's amicus brief, this time for the idea that state common law tort claims threaten the federal regulatory framework for medical devices because "they encourage, and in fact require, lay judges and juries to second-guess the balancing of benefits and risks of a specific device to their intended patient population-the central

131. See Horn, 376 F.3d at 177 (declaring that its "preemption conclusion [was] reinforced by the informed analysis found in the FDA's amicus curiae brief."); see also id. at 182 n.29 (noting Judge Fuentes' observation that his "colleagues seem to put great emphasis on the FDA's amicus brief...").

132. Horn, 376 F.3d at 166 n.5.

133. Id. at 167 n.6.

134. Id. at 170-72, 176-78.

135. Id. at 177. 
role of FDA - sometimes on behalf of a single individual or group of individuals." ${ }^{136}$ The court cites this unwillingness to allow judges and juries to second-guess the FDA as one of its primary justifications for finding that Mrs. Horn's state claims were preempted. ${ }^{137}$

In affording such high deference to the opinions expressed by the agency in its amicus brief, the court placed inappropriate reliance on the agency's interpretation of Section $360 \mathrm{k}(\mathrm{a})$. Unfortunately, the court's FDA-influenced decision created binding precedent within the Third Circuit, from which injured consumers, such as Mrs. Horn, will suffer the consequence of being left without a remedy from the entity most responsible for their injuries: the medical device manufacturers. As " $[t]$ he court, not the agency, has 'final responsibility for the interpretation of the law' under which the regulation was issued," 138 the Third Circuit should have avoided this result.

A number of federal courts have commented on the proper level of deference afforded to opinions expressed by agencies in amicus curiae briefs. The most notable of these comments comes from the Supreme Court in its 1944 Skidmore v. Swift \& Co. opinion. ${ }^{139}$ There, the Court had the task of clarifying the degree of reliance properly placed on the opinions expressed in an agency administrator's amicus brief, regarding the proper interpretation of the Fair Labor Standards Act. Recognizing that every such situation will entail a unique set of surrounding circumstances, the court outlined the following factors to be used in determining the proper amount of reliance: "the thoroughness evident in its consideration, the validity of its reasoning, its consistency with earlier and later pronouncements, and all those factors which give [the agency] power to persuade, if lacking power to control."140 Thus, the analysis is not the same in every situation. Rather, courts must look to the circumstances surrounding the formation of the agency's opinion in order to properly evaluate the amount of weight it should be afforded.

Using the Supreme Court's Skidmore opinion as a guidepost, many courts have offered their own comments on the proper amount of reliance that should be placed on the opinions expressed by agencies in amicus briefs. In Yamaha Corp. of Am. v. State Bd. of Equalization, the California Supreme Court recognized that determining the proper amount of weight to be given an agency interpretation is "fundamentally situational," requiring consideration of complex factors, such as the validity of the reasoning and consistency with

136. Id. at 178.

137. Id.

138. Yamaha Corp. of Am. v. State Bd. of Equalization, 960 P.2d 1036 n.4 (Cal. 1998) (citing Whitcomb Hotel, Inc. v. Cal. Emp. Com., 151 P.2d 233, 235 (Cal. 1944)).

139. Skidmore v. Swift \& Co., 323 U.S. 134 (1944).

140. Id. at 140; see also Reich v. Parker Fire Prot. Dist., 992 F.2d 1023, 1026 (10th Cir. 1993) (citing explicitly the Skidmore factors when asked to determine the proper amount of weight to be given to an agency administrator's interpretation of the Fair Labor Standards Act.). 
earlier pronouncements. ${ }^{141}$ The court observed, however, that "[b]ecause an interpretation is an agency's legal opinion, however 'expert,' rather than the exercise of a delegated legislative power to make law, it commands a commensurably lesser degree of judicial deference."142 From this, it becomes clear that, despite an agency's expertise, courts should only put limited reliance on agency interpretations.

More recently, a New York district court discussed the proper amount of deference that should be afforded to the Central Intelligence Agency's ("CIA") interpretation of the CIA Information Act. ${ }^{143}$ Recognizing that Skidmore was the controlling authority, the court referred to the following list of factors, outlined by the Second Circuit, that should be used to inform the analysis: "the agency's expertise, the care it took in reaching its conclusions, the formality with which it promulgates its interpretations, the consistency of its views over time, and the ultimate persuasiveness of its arguments." 144 Despite finding these factors of limited applicability due to a lack of available evidence, the court eventually afforded low deference to the CIA's interpretation of the CIA Information Act. ${ }^{145}$

Applying the Skidmore factors, along with the supplemental considerations suggested by Yamaha and American Civil Liberties Union v. Dept. of Def., one is led to question the Third Circuit's reliance on the interpretive opinions expressed by the FDA in its amicus brief. Understanding that this determination depends on the circumstances surrounding the formation of the FDA's opinions, Skidmore teaches that it is necessary to look at the thoroughness and validity of the FDA's reasoning, the consistency of the FDA's opinion with earlier pronouncements, and any other factors giving the FDA the power to persuade. ${ }^{146}$ Although the FDA appears to have been thorough in forming the opinions it expressed in its amicus brief, the validity of its reasoning is highly questionable. Specifically, the agency claims that allowing state common law tort claims to proceed against manufacturers of medical devices "can harm the public health by retarding research and development and by encouraging 'defensive labeling' by manufacturers to avoid state liability ...."147 This reasoning is unpersuasive and difficult to harmonize with the purposes of the MDA. Indeed, it is hard to comprehend how depriving injured consumers of their ability to obtain a remedy from the

141. Yamaha Corp. of Am., 960 P.2d at 1037.

142. Id. at 1036 (citing Bodinson Mfg. Co. v. Cal. Employment Comm'n, 17 Cal. 2d 321, 325-326) (Cal. 1941)); see also U.S. v. Mead Corp., 533 U.S. 218, 228 (2001).

143. ACLU v. Dep't of Def., 351 F. Supp. 2d 265 (N.Y. Dist. Ct. 2005). 2002)).

144. Id. at 269 (quoting Cmty. Health Ctr. v. Wilson-Coker, 311 F.3d 132, 138 (2d Cir.

145. Id. at 278.

146. Skidmore, 323 U.S. at 140.

147. FDA Amicus Curiae Letter Br., at 26, Horn v. Thoratec Corp., No. 02-4597 (3d Cir. May 14, 2004). 
manufacturer of the device responsible for their injuries would work to "harm the public health." 148

On the contrary, the public health would benefit from exposing manufacturers to tort liability for their injurious products in a number of respects. First, and most obviously, injured consumers would immediately benefit because they could receive compensation for their injuries. Second, exposure to tort liability would give manufacturers the incentive to take greater care in developing safe and effective medical devices, which, in turn, would lead to a decrease in the number of people who suffer debilitating, and often fatal, injuries caused by poorly constructed devices. ${ }^{149}$

One should not lose sight of the purpose underlying Congress' creation of the 1976 Medical Device Amendments: to ensure public health by enhancing the safety and effectiveness of medical devices. ${ }^{150}$ Allowing state common law tort claims is imperative to the accomplishment of this purpose only then can the FDA's purported aversion to "harm[ing] the public health" 151 be realized.

In addition to lacking validity, the opinions expressed by the FDA in its amicus brief are totally inconsistent with earlier pronouncements that the agency made on the topic of Section $360 \mathrm{k}$ (a) preemption of state common law tort claims. In fact, in the 1998 Supreme Court case of Smiths Industries Medical Systems, Inc. v. Kernats, the FDA filed an amicus brief expressing an entirely contrary opinion regarding Section $360 \mathrm{k}$ (a)'s preemptive scope. ${ }^{152}$ There, the agency explicitly opposed arguments in favor of preemption by claiming that state common law suits are desirable because they help to ensure the safety and effectiveness of medical devices. ${ }^{153}$ The FDA expressed this same opinion when it published 21 C.F.R. Section 808.1(d) in 1978, with amendments made thereto in 1980 and 1996. In particular, the FDA wrote that preemption only applies to "specific requirements applicable to a

148. Id.

149. See Robert B. Reich, A Suitable Remedy; When the FDA is Weak, WASH. Post, Jan. 9,2005 , at B5 (commenting that "the tort system has at least one large virtue: It creates a powerful financial incentive for companies to ferret out potentially harmful side effects before they market their products, and to withdraw or redesign dangerous products if and when injuries occur."); Blocking Medical Product Suits, N.Y. TIMES, Aug. 1, 2004, at 410 ("It seems poor policy to assume that once the agency has judged a product safe enough to use, the manufacturer should be insulated forever from lawsuits that could force improvements.").

150. Med. Device Amendments of 1976, Pub. L. No. 94-295, 90 Stat. 539 (1976).

151. FDA Amicus Br., supra note 147, at 26.

152. FDA Amicus Curiae Letter Br., Smiths Indus. Med. Sys., Inc. v. Kernats, 522 U.S. 1044 (1998).

153. Id.; see also Kathleen Kerr, Liability Lawsuits; Can FDA Seal Be Broken?, NEwSDAY, Aug. 11, 2004, at A26 (where the author includes the following 1997 quote by Margaret Jane Porter, chief FDA counsel during the Clinton administration: "FDA product approval and state tort liability usually operate independently, each providing a significant, yet distinct, layer of consumer protection."). 
particular device,"154 noting that "state or local requirements of general applicability" do not fall within this category. ${ }^{155}$ The agency's current stance on the issue completely contradicts its earlier pronouncements in Kernats and 21 C.F.R. Section 808.1(d), and therefore, suffers under Skidmore's consistency requirement. ${ }^{156}$ As consistency is the bedrock of legal precedence, it should not be undermined by agency waffling.

Considering the invalidity and inconsistency of the FDA's present position on the preemptive scope of Section $360 \mathrm{k}(\mathrm{a})$, the Third Circuit should have been loath to defer to the opinions expressed by the FDA in its amicus brief. As it was, however, the Third Circuit afforded great weight to the FDA's opinion in reaching its ultimate conclusion that Mrs. Horn's state common law tort claims were preempted, thereby rendering its decision vulnerable to significant criticism.

Despite these arguments, the majority in Horn justified its reliance on the FDA's amicus brief by claiming that it was bound by the Supreme Court's holding in Chevron, U.S.A. Inc. v. NRDC, Inc. to adopt the agency's interpretation. ${ }^{157}$ Under the well-known Chevron analysis, a court is confronted with two questions when reviewing an agency's construction of a statute which it administers: first, the court must look to see if "Congress has directly spoken to the precise question at issue."158 If Congress has done so, and its intent is clear, the court and the agency must give effect thereto. ${ }^{159} \mathrm{On}$ the other hand, if Congress has not directly addressed the issue, a court may not simply impose its own construction on the statute. Rather, the court must give effect to the agency's interpretation, if it is reasonable. ${ }^{160}$ Based on this framework, the Horn court maintained that, since Congress has not specifically addressed the statute's scope, it was bound to adopt the FDA's reasonable interpretation of Section $360 \mathrm{k}(\mathrm{a}){ }^{161}$

The Third Circuit was mistaken when it determined that the opinions expressed by the FDA in its amicus brief were entitled to Chevron deference. Agency interpretations of particular statutes are only afforded Chevron deference when "it appears that Congress delegated authority to the agency generally to make rules carrying the force of law, and that the agency interpretation claiming deference was promulgated in the exercise of that authority." 162 While there is little doubt that the FDA has rulemaking power,

154. 21 C.F.R. $\$ 808.1$ (d) (2005).

155. 21 C.F.R. $\S 808.1(d)(1)(2005)$.

156. See Good Samaritan Hosp. v. Shalala, 508 U.S. 402, 417 (1993) (where the Supreme Court declared that "the consistency of an agency's position is a factor in assessing the weight [its] position is due.").

157. Chevron, U.S.A., Inc. v. Nat. Res. Def. Council, Inc., 467 U.S. 837 (1984).

158. Id. at 842 .

159. Id. at $842-43$.

160. Id. at 843 .

161. Horn, 376 F.3d at 179.

162. Mead Corp., 533 U.S. at 226-27. 
its current opinion on the preemptive scope of Section $360 \mathrm{k}(\mathrm{a})$ was not "promulgated in the exercise of" its authority to make rules. ${ }^{163}$ Rather, the opinion was expressed in an amicus curiae brief, which courts such as the Seventh Circuit have expressly declared to be informal agency policy which is not entitled to Chevron deference. ${ }^{164}$ Accordingly, the Third Circuit should have applied a Skidmore, rather than Chevron, analysis to aid in determining the proper amount of weight to afford the opinions expressed by the FDA in its amicus briefs. In failing to apply a Skidmore analysis, the court placed an inappropriate amount of reliance on the FDA's informal policy opinion and created precedent that falls short of furthering the Medical Device Amendment's goal of protecting public health by ensuring the safety and effectiveness of medical devices - precedent that is binding on all federal District courts within the Third Circuit. This effectively deprives injured consumers, such as Mrs. Horn, of the ability to recover a remedy from the medical device manufacturers responsible for the harm they have suffered. Thus, the consequences of the Third Circuit's improper reliance on the FDA's amicus brief are significant.

The Third Circuit should not have afforded so much weight to the FDA's opinions, not only because doing so was out of line with applicable judicial precedent, but also because of important public policy considerations. The FDA is an administrative body, led by the Secretary of Health and Human Services, Tommy Thompson. As Mr. Thompson's position makes him a member of the president's cabinet, he is an appointed official, subject to political influences. This fact is particularly relevant to the present discussion for the following reason: under the guise of promoting tort reform, the Bush administration recently outlined plans for intervening in lawsuits involving state common law complaints against medical device manufacturers in order to persuade courts to adopt the view that such suits should be dismissed. ${ }^{165}$ This is a troubling development. As manufacturers of medical devices and pharmaceuticals contribute large sums of money to the Bush administration, ${ }^{166}$ their influence upon the administration's recent plans to block suits against

163. Id. at 227.

164. Matz v. Household Int'1 Tax Reduction Inv. Plan, 265 F.3d 572, 574 (7th Cir. 2001); see also Christensen v. Harris County, 529 U.S. 576, 587 (2000) (where the Supreme Court stated: "interpretations such as those in opinion letters - like interpretations contained in policy statements, agency manuals, and enforcement guidelines, all of which lack the force of law do not warrant Chevron-style deference.").

165. Robert Pear, In a Shift, Bush Moves to Block Medical Suits, N.Y. TIMES, July 25, 2004 (quoting New York Democrat, Rep. Maurice Hinchey, as declaring that "the administration had 'taken the F.D.A. in a radical new direction, seeking to protect drug companies instead of the public."'); see also Reich, supra note 149, at B5 ("Republicans who have been urging tort reform for years are in firm control of Congress and the White House and are intent on ... preempting lawsuits involving products already approved by regulatory agencies.").

166. FDA Prohibits Consumer Lawsuits for Faulty Pharmaceuticals, THINK \& ASK, available at http://www.thinkandask.com/news/fdadruglaw.html (last visited Mar. 7, 2005). 
them is hard to deny. United States courts should not be subjected to this pressure. On the contrary, federal courts should be insulated from the country's political climate in order to achieve the just resolution of legal battles that society has come to expect. The ability of injured consumers to recover for injuries caused by faulty medical devices should not lay victim to the oppressive sword of wealthy special interest groups.

\section{CONCLUSION}

To resolve the present debate, as well as to avoid undue deference by courts to the FDA's wavering opinion, courts need to ultimately decide upon one consistent interpretation of Section 360k(a). An efficient method for achieving this would be for the Supreme Court to revisit the issue and clarify its fractured opinion in Lohr. While the Supreme Court's opinion was clear that Section 360k(a) does not preempt state common law claims when the device in question has been approved through the expedited Section 510k substantial equivalency process, it was vague with regard to Section $360 \mathrm{k}(\mathrm{a})$ 's preemptive effect on state claims when the device has been approved through the rigorous PMA process. Therefore, the Court needs to address the issue within the context of a PMA-approved device and clarify its stance.

As a superior alternative, this debate should be settled by Congress. Recognizing the abundant confusion caused by the language of Section $360 \mathrm{k}(\mathrm{a})$ as it is presently written, Congress could either amend the preemption provision of the MDA to specifically address the statute's effect on state tort claims, or it could encourage the FDA to issue another clarification regulation.

Regardless of the method by which a remedy occurs, courts across the country need to adopt a uniform interpretation of Section $360 \mathrm{k}(\mathrm{a})$, preferably one that recognizes the continued vitality of state common law tort claims involving federally approved medical devices. The language of Section $360 \mathrm{k}$ (a) declares that states cannot impose requirements "with respect to a device" that are different from, or in addition to, the federally imposed PMA requirements for the device. Therefore, preemption should only be appropriate if the state imposes a specific requirement on a particular, PMAapproved device. Conversely, preemption is not appropriate if the state is merely imposing a generalized duty of care on the device manufacturer through a common law tort action. It would seem that this is the proper interpretation of Section $360 \mathrm{k}(\mathrm{a})$ and, consequently, the view that all courts should embrace. 